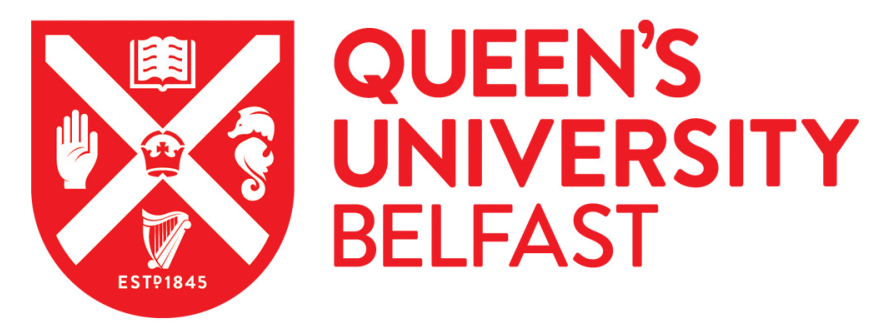

\title{
Beyond managerial talent: 'key group' identification and differential compensation practices in multinational companies
}

McDonnell, A., Gunnigle, P., Lavelle, J., \& Lamare, R. (2016). Beyond managerial talent: 'key group'

identification and differential compensation practices in multinational companies. International Journal of Human Resource Management. https://doi.org/10.1080/09585192.2015.1075571

Published in:

International Journal of Human Resource Management

Document Version:

Peer reviewed version

Queen's University Belfast - Research Portal:

Link to publication record in Queen's University Belfast Research Portal

Publisher rights

(C) 2015 Taylor \& Francis.

The Version of Record of this manuscript has been published and is available in International Journal of Human Resource Management 2016 http://www.tandfonline.com/doi/full/10.1080/09585192.2015.1075571

\section{General rights}

Copyright for the publications made accessible via the Queen's University Belfast Research Portal is retained by the author(s) and / or other copyright owners and it is a condition of accessing these publications that users recognise and abide by the legal requirements associated with these rights.

Take down policy

The Research Portal is Queen's institutional repository that provides access to Queen's research output. Every effort has been made to ensure that content in the Research Portal does not infringe any person's rights, or applicable UK laws. If you discover content in the Research Portal that you believe breaches copyright or violates any law, please contact openaccess@qub.ac.uk. 


\title{
Beyond managerial talent: 'key group' identification and differential compensation practices in multinational companies
}

\author{
Anthony McDonnell * \\ Queen’s University Management School \\ Queen’s University Belfast, 185 Stranmillis Road, \\ Belfast, Northern Ireland, \\ BT9 5EE. \\ 量严 a.mcdonnell@qub.ac.uk
}

Patrick Gunnigle \& Jonathan Lavelle

Kemmy Business School,

University of Limerick,

Ireland.

Ryan Lamare

Department of Labor Studies and Employment Relations

Penn State University

University Park, PA 16802

USA

* Corresponding author 


\begin{abstract}
With the maturation of strategic human resource management scholarship there appears to be a greater call to move from monolithic workforce management to a more strategic and differentiated emphasis on employees with the greatest capacity to enhance competitive advantage. There has been little consideration in the literature as to whether organizations formally identify key groups of employees based on their impact on organisational learning and core competences. Using survey evidence from 260 multinational companies (MNCs), this paper explores the extent to which key groups of employees are formally recognized and whether they are subject to differential compensation practices. The results demonstrate that just in excess of half of these MNCs identify a key group. There was considerable differentiation in the compensation practices between these key groups, managers and the largest occupational group in the workforce. The results give rise to questions worthy of future investigation namely, whether the differentiated approaches used lead to improved performance outcomes?
\end{abstract}

\title{
Keywords
}

Key group, compensation practices, Ireland, multinational company, rewards, strategic HRM, talent management.

\section{Introduction}

Drawing on resource-based theory (RBT), the strategic human resource management (HRM) literature proposes that there is much benefit to be derived from a preferential 
focus on employees with the greatest capacity to enhance firm performance and competitive advantage. Empirical support regarding the use of a differentiated approach relates largely to managerial talent compared to the rest of the workforce (McDonnell, Lamare, Gunnigle and Lavelle 2010). In effect, the scholarly focus has been primarily on identifying, and preferentially developing and compensating, existing and potential future leaders and senior managers. In recent times, the emergence of the talent management literature has further embellished the focus on pivotal staff (e.g. Collings and Mellahi 2009) and argues for a disproportionate investment in such employees (Boudreau and Ramstad, 2005; Becker, Huselid and Beatty 2009). This literature has to a large degree been precipitated by concerns over talent shortages across the developed and developing world (cf. Schuler, Jackson and Tarique 2011).

In this paper we contend that insufficient attention has been dedicated to employee categories, beyond managerial talent, that also possess the potential to significantly contribute to competitive advantage, and the extent to which differentiated HR approaches are implemented. A related concern, first raised by Becker and Huselid (2006), is that the literature currently emphasizes the strategic advantage of focusing on individual employees deemed to have senior management potential, without giving sufficient consideration to the need to develop and invest in cohorts of employees intrinsically involved in other roles related to core competencies within an organization. In other words, disproportionate emphasis has focused on the value of individual employees to firms without commensurate consideration afforded to the contributions of key cohorts, or groups, of employees. Yanadori and Marler (2006) focused on the compensation strategies of strategic employee groups but their 
approach was based on the premise that research and development (R\&D) jobs represented a key group without empirically testing whether the organization formally identified such a category of staff in this light. While R\&D jobs may very well represent strategic employee groups, we posit that other critical groups may also exist, especially across organizations operating in different sectors. Further, what may ostensibly appear to be a key group of employees based on their job level or position may not necessarily mean that organizations formally identify them as critical to the firm’s core competence.

The paper draws on data collected from a large-scale, representative survey of HRM practices employed by MNCs to advance understanding of the extent to which key groups of employees are formally recognized and the compensation strategy that is applied. For the purpose of this study the key groups were defined as employees that may be identified [by the respondent] as critical to a firm's organizational learning and core competence. Such groups may refer to research staff, product designers, major account handlers and so forth. Participants were then able to self-select if they formally recognized such a grouping. The objectives of this paper are twofold. First, we establish the extent to which MNCs deliberately recognize strategic employee groups that are considered vital to competitive advantage, thereby helping to counterbalance the evident focus to date on managerial and leadership development and succession. Second, we systematically investigate whether these key groups are subject to differentiated compensation practices vis-à-vis managers and the largest occupational group (i.e. largest non-managerial occupational group). The primary focus here is on whether there is differentiation in compensation strategy, often viewed as motivation enhancing HR practices (Kaifeng et al. 2012; Lepak et al. 
2006). Consequently, the paper engages with Becker and Huselid’s (2006) and Lepak and Snell's (1999, 2002) contention that an organization's workforce should not be treated as one large monolith but rather as comprising groups or categories of staff who vary in terms of their putative strategic value and for whom differing HR approaches may be utilized (also see Boxall and Purcell 2003).

We begin by reviewing relevant literature to clarify both the focus and contribution of our paper. We then describe the methodology employed, the constructs used and the statistical analysis undertaken. Following this, we present our findings. Finally, we discuss the results taking cognizance of the extant literature, and outline some pertinent conclusions.

\section{Key employees groups - the elusive ' $X$ factor' for organizations?}

The underlying theoretical framework on which this paper is grounded is RBT. More specifically, we draw on research that applies RBT to HRM through the ideas of differentiated HR architectures for different employee categories (cf. Tsui, Pearce, Porter and Tripoli 1997; Lepak and Snell 1999, 2002). The talent management literature provides further support around organizations appropriating their resources more strategically in terms of important employees and roles (Boudreau and Ramstad 2005; Collings and Mellahi 2009; McDonnell 2011).

RBT contends that sustainable competitive advantage can be achieved through the development of internal resources that are valuable, rare and difficult to imitate (Barney 1991, 1995, 2001). Such resources may include, 'all of financial, physical, human, and organizational assets used by a firm to develop, manufacture, and deliver 
products or services to its customers' (Barney 1995, p. 50). High quality human capital is often considered to satisfy the requirements set down by RBT (Takeuchi, Lepak, Wang and Takeuchi 2007) with the inimitability of resources particularly important in arguing that human capital can lead to sustainable competitive advantage. Employees are widely seen as a key means through which organizations ultimately develop capacity and skills, formal and tacit knowledge, and build relationships and networks. In particular, knowledge-based resources are seen as more idiosyncratic to the firm in which they reside (Barney 1991; Peteraf 1993).

Under RBT, managerial talent is unsurprisingly typically viewed as the most significant of human capital sources due to the predominantly tacit nature of their skills and the impact they have on setting and realizing the corporate objectives (Thompson and Heron 2005). Consequently, by definition, strong managerial and leadership capability will be difficult to replicate. It is against this backdrop, along with supply/demand concerns, that talent management has emerged as a prominent topic in the practitioner and academic lexicon.

In this paper we argue for greater consideration of high value human capital sources beyond just managerial talent. The primary value of employees derives from their capacity to contribute to the achievement of business strategies and to take advantage of the opportunities, and reduce the threats that arise in the marketplace (Barney 1991; Gonzáález and Tacorante 2004). 'The uniqueness of human capital, or firm specificity, implies skills or knowledge derived from idiosyncratic learning processes, which makes their abundance in the market improbable’ (Gonzáález and Tacorante 2004, p. 58). While the identification and effective management of 'star' or 'pivotal' 
individuals has received extensive attention (e.g. Groysberg 2010), much less focus has fallen on the extent to which organizations diagnose key or strategic groups of employees. We are interested here in whether groupings of key staff, beyond managers, who possess core competencies or knowledge considered strategically important to business success (Liao and Chung 2004), are identified and subject to differentiated management practices. Such groups may often encompass employees operating in non-managerial roles but who nevertheless substantially impact on competitive advantage through technical, product, process, customer or other knowledge and core competences (Thompson and Heron 2005).

The extent to which organizations identify such groupings is, to our knowledge, unknown. Much of the scholarship on differentiated employee categories has been on core versus peripheral staff or managerial versus non-managerial workers (e.g. Jackson, Schuler and Rivero 1989). Lepak and Snell's (2002) study examined differentiated architectures where the primary unit of analysis was the mode of employment (i.e. contract works, alliances/partnerships, knowledge-based employment and job-based employment). Further, and as previously highlighted, others (e.g. Yanadori and Marler 2006; Yanadori and Kang 2011) self-determined the strategic employee group according to employees being in R\&D jobs or not. Thus, they did not delineate if the organization actually identified these as a key group or whether other critical groupings of employees existed. Furthermore, such studies were focused on only one industry - a limitation addressed here. As a key tenet of RBT is the link between corporate strategy and an organization's internal resources, there is unlikely to be strong commonality in the make-up of who these key groups are from organization to organization. Specific competencies may be valuable in one 
organization but peripheral in another. In some firms major account handlers may possess considerable value but these may be ancillary staff in other organizations where perhaps product developers may be more critical. Therefore, our first research question asks: To what extent do MNCs formally identify key or strategic employee groupings?

Stiles and Kulvisaechana (2003) usefully note that identifying key employees does not bring competitive advantage alone but that social and organizational capital must also exist. In other words, employees themselves are not just a source of competitive advantage. They can be such a source when other factors (e.g. relationships and organizational capital) are taken into account. Consequently, it is important that organizations have effective management systems and methods of working in place, as well as practices to develop and reward key staff (Hutchinson and Purcell 2003). In so doing, staff may be enabled to make the contribution desired to facilitate the achievement of competitive advantage. As a result, one might, de facto, expect a differentiated and more sophisticated approach in the management of a key group compared to the largest occupational group. The ultimate logic of this line of inquiry is that those employees who constitute a key group would be expected to receive the greatest attention and investment and an enhanced compensation package, relative to other non-managerial employees. There may be greater similarity to managers but it could be argued that some variation in approach may still be expected.

This argumentation fits neatly with RBT, which maintains that the most critical employees must be retained and their knowledge and skills absorbed within the organization through the development of organizational systems and routines 
(Kamoche and Mueller 1995; Lepak and Snell 1999, 2002). The provision and utilization of appropriate systems and practices is vital if the knowledge and skills of key employees are to be leveraged appropriately (Barney 1995; Stiles and Kulvisaechana 2003). Consequently, coherent and integrated organizational systems and practices must support staff to provide added value to the organization (Boxall 1996). Snell (2005) maintained that the most costly 'best HR practices' will be more commonly deployed among highly valued groups of employees, with a cost-control and more 'minimalist' HR approach used for other employee categories (e.g. low or unskilled categories). This is the essence of RBT, HR architecture and talent management literatures, which argue that organizations should employ differentiated compensation and broader HR systems and practices depending on the anticipated strategic contribution employees make to the organization (Becker et al. 2009; Boxall and Purcell 2003; Delery and Shaw 2001; Lepak and Snell 1999, 2002; Tsui et al. 1997; Yanadori and Marler 2006). Yet, there is little consensus as to what differentiated HR architectures or systems look like, or the practices they should incorporate (Boselie, Dietz and Boon 2005). Yanadori and Kang (2011, p. 237) suggest that 'there is only limited empirical evidence indicating whether or not firms really differentiate across employee groups when designing HRM practices’.

The focus in this paper is on differentiated approaches to compensation strategy. Ideally, the focus would have been more holistic to incorporate aspects of recruitment, selection and development etc. but the nature of the study (see methodology section) prevented this. While a somewhat narrow view of differentiated practices is used, compensation practices are long established as promoting desirable worker behavior when appropriately designed and in keeping with business strategy (e.g. Milkovich 
and Newman 2005). Consequently, key employee groups can be expected to receive 'enhanced' rewards in an explicit effort to internalize them into the organization, increase their commitment and encourage superior performance (Lepak and Snell 2002; Becker et al. 2009). Yanadori and Marler (2006) found that high technology firms in the US differentiate their compensation systems between R\&D staff and other employees. Yet Yanadori and Kang (2011) surmise that overall much of the compensation and benefits literature is implicit on the extent to which organizations actually adopt discerned approaches by employee groups. In order to advance understanding beyond the existence of key groups and provide more explicit evidence on differentiated compensation practices our second research question is: Do MNCs employ a differentiated approach to their compensation practices according to the different employee groupings?

\section{Methodological approach}

\subsection{Research design}

This paper draws on data from the first large-scale, representative survey of HRM practices in MNCs (foreign- and indigenous-owned) operating in Ireland. In so doing, the study addresses the limitations of existing studies which too often lack comprehensiveness by failing to accurately define the population of MNCs in countries (see McDonnell, Lavelle, Gunnigle and Collings 2007; Collinson and Rugman 2010; Edwards, Marginson and Ferner 2013, for fuller discussion on this limitation with MNC focused research). Ireland is a worthwhile context for research into MNCs due to its classification as one of the world's most globalized (Kearney 2002; KOF 2010) and MNC-dependent economies (Gunnigle, Collings and Morley 
2005). While there has been much discourse on Ireland's corporate taxation rate, this does not exist as the sole factor that makes Ireland such an attractive location for foreign MNCs. Research demonstrates that MNCs establish Irish operations for a range of reasons including tax incentives, financial supports and subsidies from the state development agencies, the highly skilled workforce and location within the EU, and a generally 'business friendly’ institutional environment (Gunnigle and McGuire 2001). Despite experiencing a particularly severe economic recession, the country was recently ranked as the world's second most economically globalized country (KOF 2010), the fifteenth most competitive world economy (IMD 2014), and has experienced strong inward foreign investment flows despite the global financial crisis. While the early attraction of foreign direct investment (FDI) was very much in the lower, value-added manufacturing industries, recent decades have seen a significant change in the profile of MNCs in Ireland. For example, Ireland now acts as the European HQ for MNEs including Google, LinkedIn, and Facebook. Even amongst the early firms that established manufacturing operations in Ireland, there has been increased, valued added activity investment in recent decades. For example, Intel, IB, Hewlett Packard and Boston Scientific have established significant R\&D operations. Consequently, we believe that Ireland's FDI profile is quite varied, making it an interesting context in which to study the identification of key groups.

The first stage of the study involved the identification of an accurate population of MNCs. Indigenous-owned MNCs were defined as wholly or majority Irish-owned organizations with 500 or more employees worldwide and at least 100 employed abroad. Foreign-owned MNCs were defined as wholly or majority foreign-owned organizations operating in Ireland, with 500 or more employees worldwide and 100 or 
more employed in their Irish operations. (A detailed exposition of the methodological process followed can be found in McDonnell et al. 2007). These definitions were based on that used by the European Works Council Directive (94/45/EC) but we reduced the employment criteria from 1,000 worldwide to 500 so as to not exclude moderately sized MNCs. This resulted in a total population of 563 MNCs (491 foreign- and 72 Irish-owned). We then took a stratified, random sample of 414 MNCs according to country of ownership, employment size and sector. A key rationale behind taking a stratified sampling was the high proportion of US MNCs in the population and wanting to capture a spread of nationalities and the pragmatic issue of insufficient resources to conduct more than 300 interviews which our predicted response rate would have meant. Consequently, not all US MNCs were selected as it would have meant they were over sampled.

The second stage of the project was data collection. This took the form of a survey instrument that was administered through a face-to-face interview with the most senior HR practitioner, able to answer for all of the Irish operations. The data collection process commenced with each target respondent being sent a letter informing them of the study's aims and benefits etc., along with a letter of support from the Chartered Institute of Personnel and Development. Following this, the research team began phoning each target respondent with the aim of obtaining their participation by way of an interview. Each interview took between 40 and 60 minutes and consisted primarily of dichotomous and scale response questions with a very small number of open questions. The decision to administer the survey via interview as opposed to other forms (e.g. postal/online) was due to two main reasons. Firstly, the interview approach appears to be associated with higher response rates than other 
administration methods (Baruch and Holtom 2008). Secondly, interviews have been lauded for their ability to reduce the amount of missing data (McKnight, McKnight, Sidani and Figueredo 2007). The data collection phase resulted in a total of 260 MNCs participating (213 foreign and 47 indigenous MNCs) - an overall response rate of $63 \%$. We checked for non-response bias by analyzing the profile of the participant MNCs according to their country of origin, employment size and sector, (i.e. the criteria used for sample stratification and key variables of interest in the overall study) with the total population of MNCs. This analysis indicated no significant differences between the organisations that participated and those that did not. Table 1 highlights the key characteristics of the respondent MNCs.

Insert Table 1 here

\subsection{Measures}

This paper explores the extent to which MNCs formally identify a critical group of non-managerial employees (called the 'key group'), and whether there is a differentiated approach in compensation practices between the key group, managerial group and largest occupational group. In each interview respondents were initially provided with explanations of these employee categories.

- $\quad$ Managers - employees who primarily manage the organization, or a department, subdivision, function, or component of the organization and whose main tasks consist of the direction and coordination of the functioning of the organization. In other words, managers refer to those above the level of first-line supervision. 
- Largest Occupational Group - the largest non-managerial occupational group among the employees in the 'headcount' in Ireland. For example, in a manufacturing business it might be semi-skilled operators, and in an insurance company it might be call centre staff.

- The Key Group - those employees whom you might identify as critical to your firm’s organizational learning and core competence. These might be research staff, product designers, major account handlers, developers of new markets, etc. We do not want you to think of a subgroup of management.

The interviewees were then asked to indicate the number of managers in the Irish operations before being asked to state the name and work undertaken by the largest occupational group and the number employed in the Irish operations. Respondents were then asked to report whether they recognized a key group in the Irish operations. If they answered, 'Yes - more than one group', they were asked to focus on the group with 'the most unique skills and capabilities that may be difficult to obtain on the external labor market', ‘were the largest group’ or 'both'.

The focus in the paper was on compensation practices. This is an area where one might expect to find differences between employees based on their strategic value to the organization. Pay level policy is vital to maximizing an organization's ability to attract and retain employees as it depicts the competitiveness of pay in the market (Milkovich, Newman and Gerhart, 2014). Similarly, financial participation schemes (e.g. profit sharing) are likely to be used to assist with attracting and retaining talent and encouraging employee commitment (D’Art and Turner 2004). Overall, a firm's approach to compensation represents a cornerstone of HR strategy (e.g. Boyd and 
Salamin 2001). We recognize that this paper does not encompass the vast range of options that organizations can conceivably offer to their workforce. As the key group was an exploratory concept in our study, we only considered some of the most established and traditional compensation practices.

The first measure asks about the pay policy of the MNC with regard to where it aims to be (top quartile, $2^{\text {nd }}$ quartile, median/midpoint, below median/midpoint) in relation to pay levels and market comparators for our three employee pools. Second, we asked about whether approved employee share ownership schemes (AESOS), profit sharing and share options were offered to the key group, managers and largest occupational group. AESOS refers to where the organizations establish a trust which acquires shares on behalf of employees and provides employees with part ownership of the company. Profit sharing refers to rewards given to employees in addition to normal salary and bonuses which are dependent on the levels of profit in the business. Share options are where employees are given the option of buying company shares, often at a reduced rate. Third, we asked whether any of the employee pools received variable pay. Variable pay was defined as including, merit pay, performance related pay, performance related bonuses or payment by results. All questions measured the actual situation in the organization rather than measuring the ideal situation or intentions. A sample of some of the questions used can be found in the appendix.

\subsection{Statistical analysis}

We utilize frequency and crosstab analysis in the first part of the results section. Following this we use $\chi^{2}$ tests to compare the extent to which the key group statistically differs from the largest occupational group and managers in terms of our 
five measures of compensation practices. $\chi^{2}$ tests are particularly useful in that they assess the extent to which differences in categorical variables are statistically meaningful. We also include t-tests to measure whether differences occurred in the average number of compensation practices made available to workers. Finally, we incorporate logistic regressions to test differentiation in individual practice availability across sectors. This allows for a comparison of the extent to which our measures vary across the key group, largest occupational group, and managers depending on whether the firm belongs to traditional manufacturing, high-tech manufacturing, finance/business, retail/distribution/hotel/catering, or other sectors. Traditional manufacturing industry is used as the reference point throughout our regression analysis and we control for the company's country of origin and worldwide employment size in all models.

\section{Results}

\subsection{Descriptive Analysis: The Presence of Key Groups}

The study showed that just over half (52\%) of all MNCs identified a key group of non-managerial employees (see Table 1). No significant differences were found between whether the MNC was indigenous- or foreign-owned (52\% versus 53\% respectively). Of these, almost 32\% recognized more than one group. In such cases, we asked respondents to select the group that was most unique in that they possess skills or capabilities that are difficult to obtain in the labor market. If they could not differentiate on this basis they were then asked to select the largest group. Some 82\% of those that initially identified more than one key group were able to select one group based on having the most unique skills and capabilities; $13 \%$ selected the group based 
on this but also noted that they were the largest group, and the remaining $5 \%$ made their selection based on being the largest group.

We categorized the majority of key groups (64\%) as technical staff, which encompasses R\&D specialists, chemists, engineers, quality technicians and product designers. Key sales employees (10\%) and operational and support staff (8\%) encompassed the other main categories identified. Invariably the key group was relatively small with almost seven in ten (67\%) MNCs reporting that they encompassed less than 50 employees.

\section{$\underline{4.2 \text { Statistical Analysis: Differentiation by Employee Groups }}$}

Table 2 highlights the frequency of use for each of the compensation practices among our three groups of employees. Differences are clearly evident. The key group were the most likely to be subject of a deliberate policy which seeks to provide pay levels in the top (31\%) and $2^{\text {nd }}$ quartiles (29\%) of pay relative to market comparators. The largest occupational group were most likely to be paid at the median or midpoint level as demonstrated by the response from $60 \%$ of all MNCs. We found that the largest occupational group were the least likely to benefit from any of the three financial participation schemes. The key group were slightly more likely than managers to be offered AESOS (35\% versus 32\%) and profit sharing (35\% versus 34\%). On the other hand, managers were more likely to be offered share options (49\% for managers versus $40 \%$ for key group). Differences in the use of performance related pay between the key group and managers were limited (86\% versus 91\% respectively). However, the key group were considerably more likely to have performance related pay vis-àvis the largest occupational group. 
Insert Table 2 here

Table 3 provides the results of two-way contingency tables of differentiation in individual portions of a firm's approach to compensation. These tables compare the key group against the largest occupational group and also against managers on our five compensation practice measures. We use Pearson's $\chi^{2}$ tests (supplemented with Fisher's exact tests, though these are not reported within the table) to assess the extent to which the proportions found within each contingency table are independent. A statistically significant $\chi^{2}$ test would indicate the presence of differentiation across employee group pairings.

Insert Table 3 here

Statistically significant differences by employee group emerged when looking at the practice of compensating workers with top quartile pay $\left(\chi^{2}=45.321\right.$ when compared to the key group with the largest occupational group, $\mathrm{p}<.01 ; \chi^{2}=54.339$ and the key group with managers, $\mathrm{p}<.01$ ). Where firms recognize a key group, our results indicate differentiation between the key group and the largest occupational group in $49 \%$ of the cases. That is to say, when the key group was awarded top quartile pay, in almost half of these cases the largest occupational group was not. Further, in cases where the key group was not given pay in the top quartile, firms very rarely (only $2 \%$ of the time) chose to provide top quartile pay to the largest occupational group instead. The key group also enjoyed differentiation when compared against managers on this measure. In cases where the key group was awarded pay in the top quartile, this 
practice was not also provided for managers $36 \%$ of the time. On the other hand, when the key group was not granted high pay, managers rarely (in only $4 \%$ of the cases) received it instead. Overall, it was more often the case that the key group received top quartile pay when others did not than the reverse (i.e., other groups being in receipt of top quartile pay but not the key group).

Smaller, though still significant, variation was found in terms of AESOS for each group $\left(\chi^{2}=121.367\right.$ when comparing the key group with the largest occupational group, $\mathrm{p}<.01 ; \chi^{2}=121.539$ when comparing the key group with managers, $\mathrm{p}<.01$ ). In most cases, when the key group was given an opportunity for AESOS, so too were the largest occupational group and managers. By equal measure, whenever the key group was not included in AESOS possibilities, it was rare for any other employee groups to be offered them. Similar results were found for profit sharing $\left(\chi^{2}=109.035\right.$ when comparing the key group with the largest occupational group, $\mathrm{p}<.01 ; \chi^{2}=95.571$ when comparing the key group with managers, $\mathrm{p}<.01$ ). In $7 \%$ of cases the key group were treated differently from the largest occupational group in terms of profit sharing plans - i.e., the key group was given profit sharing but the largest occupational group was not. Differentiation for profit sharing between the key group and managers was also found in $8 \%$ of the cases; the key group was not offered this option but managers were.

Differentiation also occurred across employee groups when considering the availability of share options $\left(\chi^{2}=63.156\right.$ when comparing the key group with the largest occupational group, $\mathrm{p}<.01 ; \chi^{2}=61.472$ when comparing the key group with managers, $\mathrm{p}<.01$ ). In $38 \%$ of cases where firms offered this provision to their key 
group, they did not offer to the largest occupational group. Equally, when this option was unavailable to the key group, it was also unavailable to the largest occupational group in virtually every firm (that is, no firm offered share options to the largest occupational group but not the key group). Differentiation also occurred between the key group and managers. In nearly a quarter of cases, managers were provided with share options when the key group was not. In only $6 \%$ of cases were the key group given this option without it also being available to managers. On the whole, it was more often the case that key groups received share options when the largest occupational group did not, but it was not commonly the case that the key group received this practice without managers also enjoying.

We discovered considerable differentiation with respect to variable pay ( $\chi^{2}=16.586$ when comparing the key group with the largest occupational group, $p<.01 ; \chi^{2}=31.060$ when comparing the key group with managers, $\mathrm{p}<.01$ ). In $23 \%$ of cases, when the key group was provided with variable pay, the largest occupational group was not. However, when the key group did not receive variable pay, this pay scheme was instead provided to the largest occupational group in 32\% of cases. Equally, the key group essentially never received performance-based pay without managers also receiving it; yet, in cases where the key group did not receive variable pay, the scheme was still provided to managers $68 \%$ of the time. These results indicate that it was more often the case that the largest occupational group and managers received variable pay schemes without the key group also receiving these schemes than the reverse (i.e., the key group receiving variable pay while other groups did not). 
Moving beyond individual compensation practice differentiation, we considered whether firms offered higher numbers of aggregate practices to the different groups of employees. We counted the total number of practices employed by each firm, which could range from zero to five. Table 4 provides results for the independent samples ttest analysis of differentiation in the mean number of compensation practices at each group. The results indicate differentiation between the key group and the largest occupational group, with the key group given a greater aggregate number of practices, at 2.2 out of a possible 5 practices, compared with only 1.7 for the largest occupational group $(\mathrm{p}<.05)$. Conversely, a statistically identical number of practices were made available when comparing the key group with managers.

Insert Table 4 here

We also explored the extent to which a firm's industry shapes the extent to which our measures of compensation practices were offered to the key group, largest occupational group, and managers (Table 5). We found some variation across industries in the extent to which firms offer top quartile pay to their key groups. Finance/business companies were over six times more likely $(\mathrm{p}<.05)$ to offer this practice to their key workers than traditional manufacturing companies. A similar result was found among 'other' companies $(\mathrm{p}<.10)$. This variation was exclusive to the key group - no differentiation by industry occurred in terms of top quartile pay for the largest occupational group or for managers.

In terms of share ownership, we found no evidence of industry differences for the key group or for the largest occupational group. However, managers from high-tech 
manufacturing firms were more likely to receive AESOS than managers from traditional manufacturing companies $(\mathrm{p}<.10)$. Regarding profit sharing, there was no evidence of differentiation across industries and employee groupings. For share options, there was a small amount of differentiation. Within the key group, finance/business firms were three times more likely $(\mathrm{p}<.10)$ to provide share options than traditional manufacturing companies. There was no difference by industry in terms of share options for the largest occupational group or managers.

Looking at variable pay, we found some differentiation by industry. Among the key group, those in the 'other' category of industry were over nine times more likely $(\mathrm{p}<.10)$ to offer variable pay than traditional manufacturing companies. Conversely, within the largest occupational group, firms in 'other' industries were significantly less likely than manufacturing companies to offer their workers variable pay $\left(p^{<.10)}\right.$. Finally, for managers, firms in retail/distribution/hotels/catering were over seven times more likely to have variable pay than traditional manufacturing companies $(\mathrm{p}<.10){ }^{1}$

Insert Table 5 here

\section{Discussion, Conclusions and Implications}

Resource based theory suggests that value of human capital stems, in part, from its capacity to contribute to the achievement of business strategies (Barney 1991). Both strategic HRM and talent management scholarship has called on organizations to

\footnotetext{
${ }^{1}$ We also used chi-square tests to assess whether having one versus having more than one key group differs depending on the characteristics of the firm (country of origin, size, sector) and the answer was again, no. As such we can safely conclude that there is no difference in either the composition of the companies having one or more than one key group, nor is there any difference in the treatment of these groups in terms of compensation practices.
} 
formally recognize that some employees and roles are more important than others and then make disproportionate investments towards those strategic roles and employees (Huselid, Beatty and Becker 2005; Huselid and Becker 2011). Yanadori and Kang (2011, p. 253) remark that 'researchers seem to have accepted the notion of intra-firm differentiation of HRM systems' but that evidence on whether such differences actually occur is lacking. This paper has found that just in excess of half of the surveyed MNCs formally identify key groups of employees deemed critical to the firm's core competences and organizational learning. Consequently, the paper found some support for the need to consider the application of RBT beyond managerial talent or elites. However, it was also evident that strategically identified employee groups were not necessarily a uniformly common feature of all organizations. This we contend makes it important that future research on this topic moves beyond clustering job roles and arguing they automatically represent a key or strategic employee grouping. There is scope to develop more refined and sophisticated measures to more accurately gauge the presence of strategic employee groups beyond existing means. It could, therefore, be argued that the focus of researchers may move more in the direction of identifying various cohorts of workers as opposed to treating the workforce as one large group.

Differentiation in the application of compensation practices was common between the key group, managers and the largest occupational group. This provides support to the HR architecture and talent management literatures which stress the need for discrimination in HR practices according to strategic value and contribution of employees. Lepak and Snell (1999, p. 32) argued that, 'it may be inappropriate to simplify the nature of human capital investments and suggest that there exists a single 
optimal HR architecture for managing all employees'. Similarly, Jackson et al. (1989) noted that different groups of employees have varying importance to an organization's competitive advantage which means that the HR management approach should also vary between groups of staff. On the whole, our results that were focused on compensation pointed to the greatest magnitude of differentiation between the key group and the largest occupational group. As our second table indicates, the key group is, by and large, closer on many compensation practice offerings to managers than to the largest occupational group. This differentiation was also confirmed statistically in our third and fourth tables. This suggests that the key groups are treated as being of sufficiently greater strategic value than those performing the more operational activities of the organization (i.e. largest nonmanagerial occupational group). This result provides some support that many MNCs were adopting a contingent approach to compensation whereby particular compensation practices were only available to the key group and not the largest occupational group. There were less visible differences between the practices provided to the key group and managers.

The key group, where identified, appear therefore to be viewed as similar in strategic importance to managers. While managers are commonly provided with share options, profit sharing and share ownership schemes, it is worth noting that the key group were typically more likely to receive top quartile pay when compared to market comparators. Some differentiation by industry was evident but there was no great discernible pattern evident across all practices. The only minor pattern to emerge was that there was greater provision of top quartile pay and share options to key groups in the financial and business services sector. Overall though, the results, while 
significant, do indicate that there were less discernible differences between the key group and managers on issues like top quartile pay and share options. This poses a key question, worthy of future investigation, as to whether organizations have the right balance in their compensation strategy to motivate and retain employees that are encompassed both across and within these key groupings. Lepak and Snell (1999, p. 42) contend that, 'despite the practical appeal and theoretical parsimony of a "onesize-fits-all” approach to HR management, employment modes in most organizations are not this homogenous, and HR systems are rarely this monolithic'. Our results suggest that variation may exist beyond an employment mode or type conceptualization. This, we contend, intimates that greater attention is needed on the potential differences in the people management systems applied in organizations across different employee groups. This is something which talent management scholars are increasingly recommending to organizations (e.g. Collings and Mellahi 2009).

We are cognizant that like any research study, there are some limitations that should be identified. The use of a single respondent (Bowman and Ambrosini 1997) could be construed as a possible limitation and is thus acknowledged. In saying that, we argue that our selection of the most senior HR practitioner helps offset this due to their expertise (see Wright, Gardner, Moynihan and Park 2001). In other words, the respondent was the key informant. To further reduce the possibility of there being an issue with drawing on a single-respondent input, informants were advised in advance of the information we would be seeking and, following advice of scholars, we spent a significant degree of time on developing and piloting the instrument before administration (Wright et al. 2001). 
Additionally, although we capture a variety of reward practices in our data set, we are limited by the possibility that other practices might be available to employees that are not included in our data set. These omitted variables might affect our fourth table in particular, where we find that the absolute number of practices available across a firm varies between the LOG and the key group. It remains possible that other practices, for which we do not account in our questionnaire, might conceivably be given to the LOG but not the key group, which would diminish evidence in differentiation across the absolute number of reward practices provided. We therefore urge some caution in interpreting the results from the fourth table, and recommend that future research endeavors to more holistically assess differentiation by employee groups in terms of the total award practices made available.

We view this research as a starting point to further explore whether organizations actually formally determine strategic employee groupings and whether they subsequently adopt discerning managerial approaches to them. Future research that seeks to establish if the differentiated practices in place for the various employee groups lead to improved productivity and performance would be most worthwhile. Our study was only able to provide descriptive evidence on the use of compensation practices; we were unable to consider the impact on different facets of performance. High quality human capital is not sufficient in its own right to build competitive advantage. Firms need to be organized in a way that enables them to effectively use their talent in the best means (Ulrich and Lake 1991; Barney 1995). We call for research exploring the HR approaches adopted for each employee group and their impact on productivity and performance. While there is endorsement of 
differentiating HRM systems by employee groups, there has been some evidence that points to negative consequences from diversity of compensation practices (Bloom 1999). There is little doubt that this research lends itself to being illuminated through the use of multiple methodological approaches.

Ideally, the study would have incorporated additional parts of HRM systems. We are conscious of the emerging talent management literature and the importance placed on intrinsic factors, development and career management. Being able to explore such aspects would have undoubtedly allowed greater determinations to be made and such an expansion is recommended in follow-up research. For instance, the collection of additional data on career management, development activities and relationships with job performance and turnover would be useful to allow greater conclusions to be made, such as the impact of practices on different groups of employees. The Abilities, Motivation, Opportunity to participate model (i.e. AMO-model) is popular in this type of research (e.g. Boselie et al. 2005; Edwards, Tregaskis, Sanchez-Mangas, Levesque, McDonnell and Quintanilla 2013). Our focus here was on extrinsic financial factors (i.e. the motivation dimension) but we recommend that future research in this area would expand on the financial factors to also include practices that relate the ' $\mathrm{A}$ ' and 'O’ dimension. Being able to demonstrate variety on a fuller spectrum of HR practices and policies would undoubtedly add considerably. This paper does, however, represent a useful starting point. The use of a longitudinal research design would also be worthwhile to allow one to decipher if there is greater or less identification of key groups and changes in the HR approaches used over time. 
Some MNCs recognized more than one key group but due to the nature of this research project respondents were forced to select one key group only. In future, researchers might explore whether there are differentiated HR practices between different key groups within the one organization. Being able to develop greater depth to the characteristics of the key group concept and how organizations go about formally identifying this group would be of considerable value. A final point worthy of future consideration is garnering an understanding of whether particular contextual factors predict the identification and management of key groups (e.g. occupational nature, country of ownership, strategic roles).

\section{References}

Barney, J. (2001), 'Is the Resource-Based "View” A Useful Perspective for Strategic Management Research? Yes,' Academy of Management Review, 26(1), 41-56. Barney, J. (1995), 'Looking Inside For Competitive Advantage’, Academy of Management Executive, 9, 49-61.

Barney, J. (1991), ‘Firm Resources And Sustained Competitive Advantage,’ Journal of Management, 17, 99-120.

Baruch, Y., and Holtom, B.C. (2008), 'Survey Response Levels and Trends in Organizational Research,' Human Relations, 61, 1139-1160.

Becker, B.E., and Huselid, M.A. (2006), 'Strategic Human Resources Management: Where Do We Go From Here?,' Journal of Management, 32, 898-925.

Becker, B.E., Huselid, M.A., \& Beatty, R.W. (2009), The Differentiated Workforce: Transforming Talent Into Strategic Impact, Boston: Harvard Business Press. Bloom, M. (1999), ‘The Performance Effects Of Pay Dispersion On Individuals And Organizations,' Academy of Management Journal, 42, 25-40. 
Boselie, P., Dietz, G., and Boon, C. (2005), 'Commonalities and Contradictions in HRM and Performance Research,' Human Resource Management Journal, 15, $67-94$.

Boudreau, J.W., and Ramstad, P.M. (2005), 'Talentship, Talent Segmentation, and Sustainability: A New HR Decision Science Paradigm for a new Strategy Definition,’ Human Resource Management, 42, 129-136.

Boxall, P. (1996), 'The Strategic HRM Debate and the Resource-Based View of the Firm,’ Human Resource Management Journal, 6, 59 -75.

Boxall, P., and Purcell, J. (2003), Strategy and Human Resource Management, Basingstoke: Palgrave Macmillan.

Bowman, C., and Ambrosini, V. (1997), ‘Using Single Respondents In Strategy Research,’ British Journal of Management, 8, 119-131.

Boyd, B. K., and Salamin, A. (2001), ‘Strategic Reward Systems: A Contingency Model Of Pay System Design,’ Strategic Management Journal, 22, 777-792

Collings, D.G., and Mellahi, K. (2009), 'Strategic Talent Management: A Review And Research Agenda,' Human Resource Management Review, 19, 304-313. Collinson, S., and Rugman, A.M. (2010), 'Case Selection Biases In Management Research: The Implications For International Business Studies,' European Journal of International Management, 4(5), 441-463.

Delery, J. E., and Shaw, J.D. (2001), 'The Strategic Management Of People In Work Organizations: Review, Synthesis, And Extension,’' Research in Personnel and Human Resource Management, 20, 165-197.

D’Art, D., and Turner, T. (2004), ‘Profit Sharing, Firm Performance And Union Influence In Selected European Countries,' Personnel Review, 33, 335-350. 
Edwards,T., Marginson, P., and Ferner, A. (2013), 'Multinational Companies in Cross-National Context: Integration, Differentiation and the Interactions between MNCs and Nation States,' Industrial and Labor Relations Review, 66, 547-587.

Edwards, P., Tregaskis, O., Sánchez-Mangas, R., Levesque, C., McDonnell, A., and Quintanilla, J. (2013), 'Human Resource Practices In The Multinational Company: A Test Of System, Societal And Dominance Effects,' Industrial and Labor Relations Review, 66(3), 588-615.

Gonzáález, S.M., and Tacorante, D.V. (2004), ‘A New Approach To The Best Practices Debate: Are Best Practices Applied To All Employees In The Same Way?,' The International Journal of Human Resource Management, 15, 5675.

Groysberg, B. (2010), Chasing Stars: The Myth Of Talent And The Portability Of Performance, New Jersey and Oxfordshire: Princeton University Press.

Gunnigle, P., Collings, D.G., and Morley, M.J. (2005), ‘Exploring The Dynamics Of Industrial Relations In US Multinationals: Evidence From The Republic Of Ireland,’ Industrial Relations Journal, 36, 241-256.

Gunnigle, P., and McGuire, D. (2001), ‘Why Ireland? A Qualitative Review Of The Factors Influencing The Location Of US Multinationals In Ireland With Particular Reference To The Impact Of Labour Issues,' Economic and Social Review, 32, 43-67.

Huselid, M.A., and Becker, B.E. (2011), 'Bridging Micro And Macro Domains: Workforce Differentiation And Strategic Human Resource Management,' Journal of Management, 37, 421-428. 
Huselid, M.A., Beatty, R.W., and Becker, B.E. (2005), ““A players” or “A positions?” The Strategic Logic Of Workforce Management,' Harvard Business Review, December, 110-117.

Hutchinson, S., and Purcell, J. (2003), Bringing Policies To Life: The Vital Role Of Line Managers In People Management, London: Chartered Institute of Personnel Development (CIPD).

IMD. (2014), IMD World Competitiveness Yearbook 2014, Lausanne, Switzerland: IMD World Competiveness Centre.

Jackson, S.E., Schuler, R.S., and Rivero, J.C. (1989), 'Organizational Characteristics As Predictors Of Personnel Practices,’ Personnel Psychology, 42, 727-786.

Kaifeng, J., Lepak, D., Jia, J., and Baer, J. (2012), ‘How Does Human Resource Management Influence Organizational Outcomes? A Meta-Analytic Investigation Of Mediating Mechanism,’ Academy of Management Journal, $55,1264-1294$.

Kamoche, K., and Mueller, E. (1995), 'Human Resources and Competitive Advantage: An Approximatability-Learning Perspective,' Working Paper PR 512, Aston University Business School, UK.

Kearney, A.T. (2002), ‘Globalization's Last Hurrah?’, Foreign Policy, January/February, 38-51.

KOF. (2010), KOF Index of Globalization, Downloaded from: http://globalization.kof.ethz.ch/static/pdf/rankings_2010.pdf [20 January 2010].

Lepak, D.P., Liao, H., Chung, Y., and Harden, E.E. (2006), ‘A Conceptual Review Of Human Resource Management Systems In Strategic Human Resource Management Research,' Research in personnel and human resource 
management, in ed. J.J. Martocchio, Greenwich, CT: JAI, vol. 25, pp. 217271.

Lepak, D., and Snell, S. (1999), 'The Human Resource Architecture: Toward A Theory Of Human Capital Allocation And Development,' Academy of Management Review, 24, 31-48.

Lepak, D., and Snell, S. (2002), 'Examining The Human Resource Architecture: The Relationships Among Human Capital, Employment, And Human Resource Configurations,' Journal of Management, 28, 517-543.

Liao, H., and Chuang, A. (2004), ‘A Multi-Level Investigation of Factors, Influencing Employee Service Performance and Customer Outcomes,' Academy of Management Journal, 47, 41-58.

McDonnell, A. (2011), 'Still Fighting the War for Talent? Bridging the Science versus Practice Gap,’ Journal of Business and Psychology, 26(2), 169-173.

McDonnell, A., Lamare, R., Gunnigle, P., and Lavelle, J. (2010), 'Developing Tomorrow's Leaders - Evidence Of Global Talent Management In Multinational Enterprises,' Journal of World Business, 45(2), 150-160.

McDonnell, A., Lavelle, J., Gunnigle, P., and Collings, D.G. (2007), 'Management Research On Multinational Corporations: A Methodological Critique,' Economic and Social Review, 38(2), 235-258.

McKnight, P.E., McKnight, K.M., Sidani, S., and Figueredo, A.J. (2007), Missing Data: A Gentle Introduction, New York: Guilford Press.

Milkovich, G., Newman, J. and Gerhart, B. (2014) Compensation, $11^{\text {th }}$ edition, Singapore, McGraw Hill.

Peteraf, M.A. (1993), 'The Cornerstones of Competitive Advantage: A ResourceBased View,' Strategic Management Journal, 14, 179-191. 
Schuler, R.S., Jackson, S.E., and Tarique, I. (2011), ‘Global Talent Management And Global Talent Challenges: Strategic Opportunities for IHRM', Journal of World Business, 46, 506-516.

Snell, S. (2005), 'Human Resource Strategy And Organizational Learning: Extending The Architecture In An Era Of Competitive Potential,' paper presented at the $13^{\text {th }}$ Annual John Lovett Memorial Lecture, University of Limerick, Ireland.

Stiles, P., and Kulvisaechana, S. (2003), Human Capital and Performance: A Literature Review, Cambridge: Judge Institute of Management, University of Cambridge.

Takeuchi, R., Lepak, D., Wang, H., and Takeuchi, K. (2007), ‘An Empirical Examination Of The Mechanisms Mediating Between High-Performance Work Systems And The Performance Of Japanese Organizations,' Journal of Applied Psychology, 92(4), 1069-1083.

Thompson, M., and Heron, P. (2005), 'Management Capability And High Performance Work Organization,’' International Journal of Human Resource Management, 16, 1029-1048.

Tsui, A.S., Pearce, J.L., Porter, L.W., and Tripoli, A.M. (1997), ‘Alternative Approaches To The Employee-Organization Relationship: Does Investment In Employees Pay Off?,' Academy of Management Journal, 40, 1089-1121.

Ulrich, D., and Lake, D. (1991), ‘Organizational Capability: Creating Competitive Advantage,' Academy of Management Executive, 7, 77-92.

Wright, P., Gardner, T., Moynihan, L., and Park, H.-J. (2001), 'Measurement Error in Research on Human Resources and Firm Performance: Additional Data and Suggestions for Future Research,’ Personnel Psychology, 54, 875-902. 
Yanadori, Y., and Kang, S.-C. (2011), 'Intra-firm Differentiation Of Compensation Systems: Evidence From US High-Technology Firms,' Human Resource Management Journal, 21, 236-257.

Yanadori, Y., and Marler, J.H. (2006), 'Compensation Strategy: Does Business Strategy Influence Compensation In High-Technology Firms?,' Strategic Management Journal, 27, 559-570. 
Table 1: Characteristics of Participating MNCs

\begin{tabular}{|c|c|c|c|c|c|c|}
\hline Country of origin & Ireland & US & UK & Europe & $\begin{array}{c}\text { Rest of } \\
\text { world }\end{array}$ & Total \\
\hline \multicolumn{7}{|l|}{ Worldwide Employment } \\
\hline$<500-999$ & $19 \%$ & $6 \%$ & 0 & $5 \%$ & 0 & $7 \%$ \\
\hline $1,000-4,999$ & $51 \%$ & $15 \%$ & $20 \%$ & $24 \%$ & $7 \%$ & $24 \%$ \\
\hline $5,000-29,999$ & $28 \%$ & $32 \%$ & $40 \%$ & $33 \%$ & $57 \%$ & $34 \%$ \\
\hline $30,000-59,999$ & $2 \%$ & $20 \%$ & $17 \%$ & $10 \%$ & $14 \%$ & $13 \%$ \\
\hline$\geq 60,000$ & 0 & $28 \%$ & $23 \%$ & $29 \%$ & $21 \%$ & $22 \%$ \\
\hline \multicolumn{7}{|l|}{ Irish Employment } \\
\hline $100-499$ & $26 \%$ & $56 \%$ & $51 \%$ & $70 \%$ & $71 \%$ & $54 \%$ \\
\hline $500-999$ & $17 \%$ & $17 \%$ & $17 \%$ & $13 \%$ & $21 \%$ & $16 \%$ \\
\hline$\geq 1,000$ & $58 \%$ & $27 \%$ & $31 \%$ & $18 \%$ & $7 \%$ & $30 \%$ \\
\hline \multicolumn{7}{|l|}{ Primary Sector } \\
\hline Traditional manufacturing & $30 \%$ & $9 \%$ & $20 \%$ & $11 \%$ & $7 \%$ & $15 \%$ \\
\hline High-tech manufacturing & $4 \%$ & $48 \%$ & $6 \%$ & $38 \%$ & $43 \%$ & $32 \%$ \\
\hline $\begin{array}{l}\text { Financial \& business } \\
\text { services }\end{array}$ & $21 \%$ & $37 \%$ & $34 \%$ & $27 \%$ & $21 \%$ & $30 \%$ \\
\hline Key Group Recognition & $53 \%$ & $50 \%$ & $49 \%$ & $58 \%$ & $50 \%$ & $52 \%$ \\
\hline \multicolumn{7}{|l|}{ Key Group Type: } \\
\hline Technical staff & $42 \%$ & $80 \%$ & $63 \%$ & $58 \%$ & $71 \%$ & $64 \%$ \\
\hline Senior managers & $13 \%$ & 0 & $6 \%$ & 0 & 0 & $3 \%$ \\
\hline Other managers & $13 \%$ & $2 \%$ & $13 \%$ & $3 \%$ & 0 & $5 \%$ \\
\hline Sales & $8 \%$ & $6 \%$ & $13 \%$ & $17 \%$ & 0 & $10 \%$ \\
\hline Customer-related staff & 0 & $2 \%$ & 0 & 0 & 0 & $1 \%$ \\
\hline Operational and support & $17 \%$ & $4 \%$ & 0 & $8 \%$ & $29 \%$ & $8 \%$ \\
\hline Other & $8 \%$ & $6 \%$ & $6 \%$ & $14 \%$ & 0 & $8 \%$ \\
\hline \multicolumn{7}{|l|}{ Key Group Size: } \\
\hline $1-49$ & $67 \%$ & $61 \%$ & $77 \%$ & $69 \%$ & $71 \%$ & $67 \%$ \\
\hline$\geq 50$ & $33 \%$ & $39 \%$ & $24 \%$ & $31 \%$ & $29 \%$ & $33 \%$ \\
\hline
\end{tabular}

$\mathrm{N}=260$ (total sample); $\mathrm{N}=135$ (Key Group sample). Percentages rounded up. 
Table 2: Frequency Analysis of HR Practices Used Per Employee Category (Total N Values in Brackets)

\begin{tabular}{|c|c|c|c|}
\hline & LOG & Key Group & Managers \\
\hline Pay Policy & $(245)$ & (127) & (247) \\
\hline To be in Top Quartile & $18 \%$ & $31 \%$ & $23 \%$ \\
\hline To be in $2^{\text {nd }}$ Quartile & $21 \%$ & $29 \%$ & $29 \%$ \\
\hline To be at the Median & $60 \%$ & $40 \%$ & $48 \%$ \\
\hline Below the Median & $1 \%$ & 0 & $0.4 \%$ \\
\hline \multicolumn{4}{|l|}{ Financial Participation Schemes } \\
\hline Employee Share Ownership & $30 \%(254)$ & $35 \%(130)$ & $32 \%(253)$ \\
\hline Profit Sharing & $27 \%(236)$ & $35 \%(124)$ & $34 \%(236)$ \\
\hline Share Options & $24 \%(241)$ & $40 \%(128)$ & $49 \%(244)$ \\
\hline \multicolumn{4}{|l|}{ Variable Pay } \\
\hline Merit or Performance-Based Pay & $67 \%(257)$ & $86 \%(134)$ & $91 \%(255)$ \\
\hline Mean Number of Reward Practices & 1.7 & 2.2 & 2.4 \\
\hline
\end{tabular}

LOG refers to the company’s largest occupational group. Percentages rounded up. 
Table 3: Two-way Contingency Tables of Individual Compensation Reward Practices by Employee Group

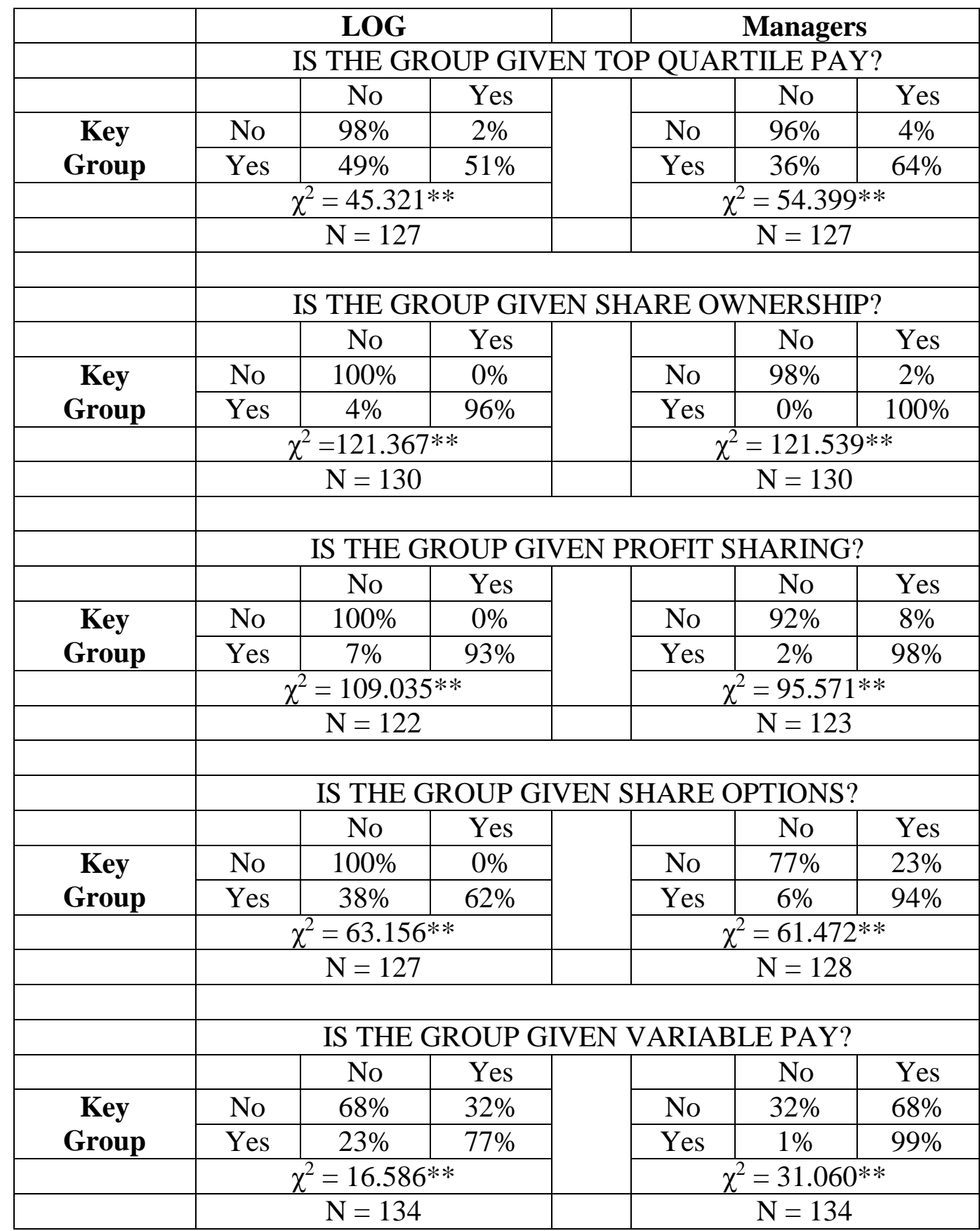

** = significant at .01 level; $*$ = significant at .05 level; ${ }^{+}=$significant at .10 level Percentages rounded up.

The 'no/no' and 'yes/yes' values indicate identical treatment between the key group and the LOG refers to the company's largest occupational group.

LOG/managers. The 'yes/no' and 'no/yes' values indicate differentiated treatment between the key group and the LOG/managers.

Note: Pearson's $\chi^{2}$ values are reported for each two-way contingency table. Since these values can be unreliable for small sample sizes, Fisher's exact test has also been run though it is not reported in the table. No differences in statistical significance are found when using Fisher's exact test instead of Pearson's $\chi^{2}$ test. 
Table 4: Means and T-Tests for Counts of Compensation Reward Practices by Employee Group

\begin{tabular}{|c|c|c|c|}
\hline Variable & LOG Mean & Key Group Mean & Managers Mean \\
\hline $\begin{array}{c}\text { Number of Compensation } \\
\text { Reward Practices }\end{array}$ & 1.7 & 2.2 & 2.4 \\
\hline $\begin{array}{l}\text { Difference between Key } \\
\text { Group and LOG/Managers }\end{array}$ & \multicolumn{2}{|c|}{$0.49 *$} & -0.20 \\
\hline
\end{tabular}

$\mathrm{N}=115$

$* *=$ significant at .01 level; $*$ = significant at .05 level; ${ }^{+}=$significant at .10 level

Note: These results assume a continuous, rather than categorical, count of the number of reward practices by employee group. Under a categorical assumption, the appropriate approach would be a series of $\chi^{2}$ tests on contingency tables. These contingency table $\chi^{2}$ tests have been run and produce results demonstrating differentiation between the LOG and key groups, as well as much smaller differentiation between key groups and managers. For ease of interpretation, we report the t-test results in this paper, but contingency table results are available on request. 
Table 5: Logistic Regression of Compensation Reward Practices by Industry Sector

\begin{tabular}{|c|c|c|c|c|c|c|c|}
\hline & \multicolumn{2}{|c|}{$\begin{array}{c}\text { Key Group } \\
(\mathrm{N}=120)\end{array}$} & \multicolumn{2}{|c|}{$\begin{array}{c}\text { LOG } \\
(\mathrm{N}=245)\end{array}$} & \multicolumn{2}{|c|}{$\begin{array}{l}\text { Managers } \\
(\mathrm{N}=247)\end{array}$} \\
\hline & & $\begin{array}{l}\text { Coeff. } \\
\text { (S.E.) }\end{array}$ & Odds & $\begin{array}{l}\text { Coeff. } \\
\text { (S.E.) }\end{array}$ & Odds & $\begin{array}{l}\text { Coeff. } \\
\text { (S.E.) }\end{array}$ & Odds \\
\hline \multirow{4}{*}{$\begin{array}{c}\text { Top- } \\
\text { Quartile Pay }\end{array}$} & $\begin{array}{c}\text { High-Tech } \\
\text { Manufacturing }\end{array}$ & $\begin{array}{l}.890 \\
(.977)\end{array}$ & 2.435 & $\begin{array}{l}-.979 \\
(.598)\end{array}$ & .375 & $\begin{array}{l}.015 \\
(.594)\end{array}$ & 1.015 \\
\hline & $\begin{array}{l}\text { Finance/ } \\
\text { Business }\end{array}$ & $\begin{array}{l}1.838^{*} \\
(.894)\end{array}$ & 6.283 & $\begin{array}{l}-.151 \\
(.534)\end{array}$ & .860 & $\begin{array}{c}.585 \\
(.540)\end{array}$ & 1.795 \\
\hline & $\begin{array}{l}\text { Retail/Distribution/ } \\
\text { Hotels/Catering }\end{array}$ & $\begin{array}{c}1.017 \\
(1.031)\end{array}$ & 2.766 & $\begin{array}{c}.197 \\
(.592)\end{array}$ & 1.217 & $\begin{array}{c}.828 \\
(.587)\end{array}$ & 2.290 \\
\hline & Other & $\begin{array}{c}1.765^{+} \\
(1.001) \\
\end{array}$ & 5.846 & $\begin{array}{l}-.412 \\
(.784) \\
\end{array}$ & .662 & $\begin{array}{l}1.063 \\
(.669) \\
\end{array}$ & 2.894 \\
\hline \multirow{4}{*}{$\begin{array}{c}\text { Share } \\
\text { Ownership }\end{array}$} & $\begin{array}{c}\text { High-Tech } \\
\text { Manufacturing }\end{array}$ & $\begin{array}{c}.811 \\
(.710)\end{array}$ & 2.250 & $\begin{array}{c}.779 \\
(.517)\end{array}$ & 2.179 & $\begin{array}{l}.861^{+} \\
(.506)\end{array}$ & 2.366 \\
\hline & $\begin{array}{l}\text { Finance/ } \\
\text { Business }\end{array}$ & $\begin{array}{l}.131 \\
(.662)\end{array}$ & 1.140 & $\begin{array}{l}.207 \\
(.486)\end{array}$ & 1.230 & $\begin{array}{c}.252 \\
(.474)\end{array}$ & 1.287 \\
\hline & $\begin{array}{l}\text { Retail/Distribution/ } \\
\text { Hotels/Catering }\end{array}$ & $\begin{array}{l}-.494 \\
(.828)\end{array}$ & .610 & $\begin{array}{l}-.064 \\
(.547)\end{array}$ & .938 & $\begin{array}{l}-.166 \\
(.538)\end{array}$ & .847 \\
\hline & Other & $\begin{array}{l}-1.719 \\
(1.223)\end{array}$ & .179 & $\begin{array}{l}-.851 \\
(.869)\end{array}$ & .427 & $\begin{array}{l}-1.009 \\
(.862)\end{array}$ & .365 \\
\hline \multirow{4}{*}{$\begin{array}{l}\text { Profit } \\
\text { Sharing }\end{array}$} & $\begin{array}{c}\text { High-Tech } \\
\text { Manufacturing }\end{array}$ & $\begin{array}{l}-.442 \\
(.686)\end{array}$ & .642 & $\begin{array}{l}-.026 \\
(.513)\end{array}$ & .974 & $\begin{array}{l}-.124 \\
(.490)\end{array}$ & .883 \\
\hline & $\begin{array}{l}\text { Finance/ } \\
\text { Business }\end{array}$ & $\begin{array}{l}.186 \\
(.630)\end{array}$ & 1.205 & $\begin{array}{l}.271 \\
(.475)\end{array}$ & 1.312 & $\begin{array}{l}.185 \\
(.458)\end{array}$ & 1.203 \\
\hline & $\begin{array}{c}\text { Retail/Distribution/ } \\
\text { Hotels/Catering }\end{array}$ & $\begin{array}{l}-.239 \\
(.799) \\
\end{array}$ & .788 & $\begin{array}{l}-.447 \\
(.574)\end{array}$ & .640 & $\begin{array}{l}-.132 \\
(.519)\end{array}$ & .876 \\
\hline & Other & $\begin{array}{l}.644 \\
(.774)\end{array}$ & 1.903 & $\begin{array}{l}-.125 \\
(.698)\end{array}$ & .883 & $\begin{array}{l}.546 \\
(.620)\end{array}$ & 1.726 \\
\hline \multirow{4}{*}{$\begin{array}{c}\text { Share } \\
\text { Options }\end{array}$} & $\begin{array}{c}\text { High-Tech } \\
\text { Manufacturing }\end{array}$ & $\begin{array}{c}.865 \\
(.693) \\
\end{array}$ & 2.374 & $\begin{array}{l}-.610 \\
(.514)\end{array}$ & .543 & $\begin{array}{c}.452 \\
(.484)\end{array}$ & 1.572 \\
\hline & $\begin{array}{l}\text { Finance/ } \\
\text { Business }\end{array}$ & $\begin{array}{l}1.142^{+} \\
(.650)\end{array}$ & 3.133 & $\begin{array}{l}-.094 \\
(.478)\end{array}$ & .910 & $\begin{array}{c}.332 \\
(.449)\end{array}$ & 1.394 \\
\hline & $\begin{array}{l}\text { Retail/Distribution/ } \\
\text { Hotels/Catering }\end{array}$ & $\begin{array}{c}.457 \\
(.789)\end{array}$ & 1.579 & $\begin{array}{l}-.632 \\
(.597)\end{array}$ & .532 & $\begin{array}{l}-.477 \\
(.510)\end{array}$ & .621 \\
\hline & Other & $\begin{array}{l}-.601 \\
(.961)\end{array}$ & .548 & $\begin{array}{l}-.734 \\
(.747)\end{array}$ & .480 & $\begin{array}{l}-.302 \\
(.619)\end{array}$ & .739 \\
\hline \multirow{4}{*}{$\begin{array}{l}\text { Variable } \\
\text { Pay }\end{array}$} & $\begin{array}{c}\text { High-Tech } \\
\text { Manufacturing }\end{array}$ & $\begin{array}{l}.646 \\
(.845)\end{array}$ & 1.909 & $\begin{array}{l}-.150 \\
(.459)\end{array}$ & .861 & $\begin{array}{c}.404 \\
(.687)\end{array}$ & 1.497 \\
\hline & $\begin{array}{l}\text { Finance/ } \\
\text { Business }\end{array}$ & $\begin{array}{l}1.276 \\
(.789)\end{array}$ & 3.584 & $\begin{array}{l}.730 \\
(.457)\end{array}$ & 2.076 & $\begin{array}{c}.824 \\
(.664)\end{array}$ & 2.280 \\
\hline & $\begin{array}{c}\text { Retail/Distribution/ } \\
\text { Hotels/Catering }\end{array}$ & $\begin{array}{c}1.520 \\
(1.018)\end{array}$ & 4.573 & $\begin{array}{l}.137 \\
(.493)\end{array}$ & 1.146 & $\begin{array}{l}1.978^{+} \\
(1.122)\end{array}$ & 7.228 \\
\hline & Other & $\begin{array}{l}2.320^{+} \\
(1.252) \\
\end{array}$ & 10.176 & $\begin{array}{l}-.991^{+} \\
(.593) \\
\end{array}$ & .371 & $\begin{array}{c}.753 \\
(.883) \\
\end{array}$ & 2.124 \\
\hline
\end{tabular}

** = significant at .01 level; $*$ = significant at .05 level; ${ }^{+}=$significant at .10 level

Controls: country of origin and employment size. Reference category: traditional manufacturing 


\section{Appendix - Sample of relevant questions from the survey}

Thinking of policy in [COMPANY NAME] in Ireland as a whole on pay levels in relation to market comparators, do [COMPANY NAME] in Ireland aim to be...?

[READ OUT SHOWCARD 15 - CODE ONLY ONE FOR EACH CATEGORY]

[READ OUT: Please include formal and informal policy]

[READ IF NECESSARY: The median/midpoint is the middle value or 50th percentile i.e. if 'the median' is selected, the aim is to have pay levels at the centre/middle point in relation to market comparators.]

\section{$\underline{\text { SHOWCARD } 15}$}

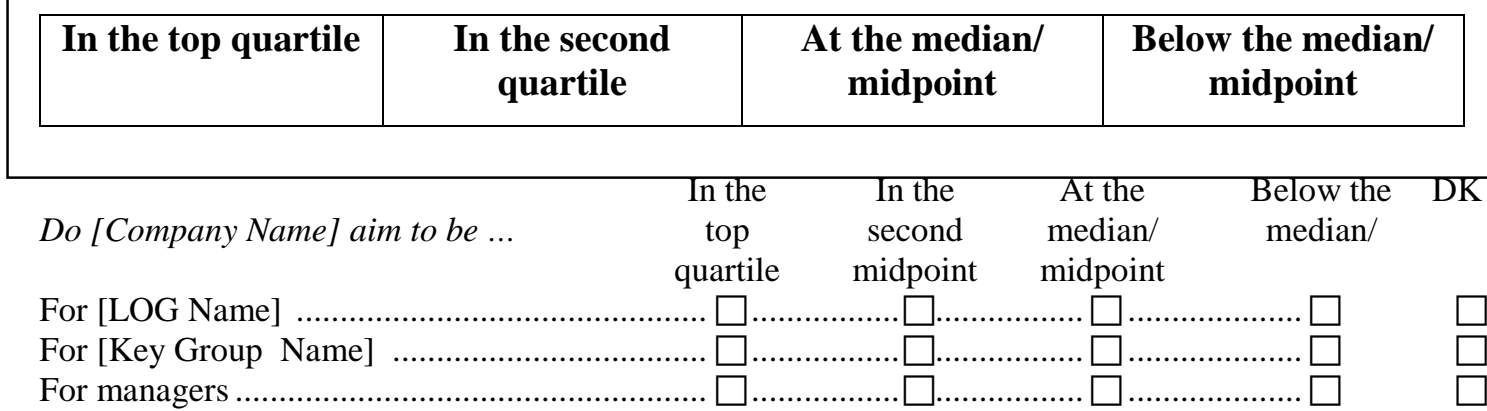

Does [COMPANY NAME] in Ireland offer the following to any employees in each of these groups? [READ OUT SHOWCARD 16]

\section{SHOWCARD 16}

1. Approved employee share ownership scheme (AESOS) is where the organisation establishes a trust which acquires shares on behalf of employees and provides employees with part ownership of the company.

2. Profit sharing refers to rewards given to employees in addition to normal salary and bonuses which are dependent on the levels of profit in the business.

3. Share options is where employees are given the option of buying company shares, often at a reduced rate.

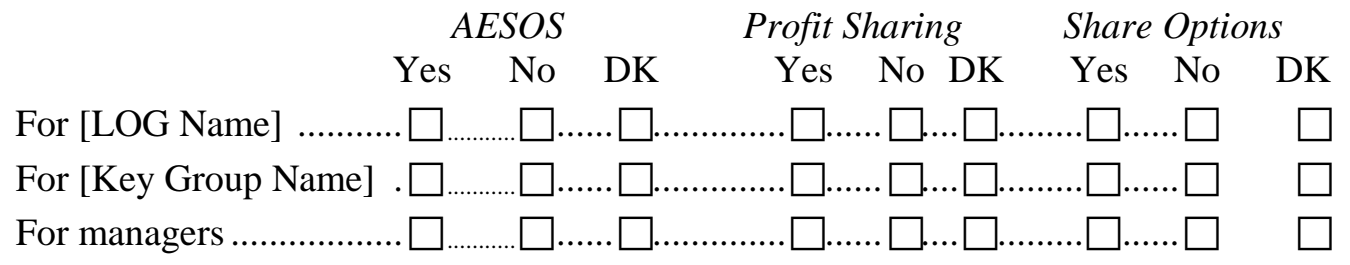

Note: DK = Don't know

IS there variable pay for the following groups in [COMPANY NAME] in Ireland? By variable pay we mean merit pay, performance related pay, performance related bonuses or payment by results

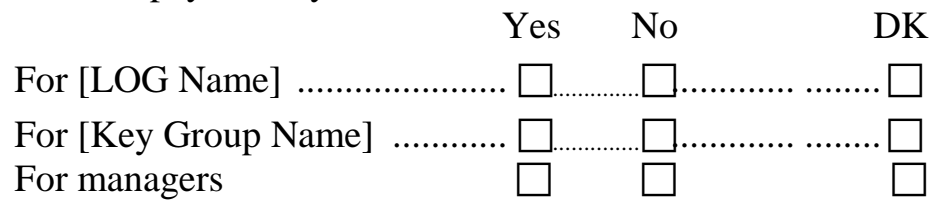

